Journal of Education and Vocational Research

Vol. 3, No. 11, pp. 353-369, Nov 2012 (ISSN 2221-2590)

\title{
Managers versus Students: New Approach in Improving Capital Structure Education
}

\author{
Anton Miglo \\ School of Business, University of Bridgeport, Bridgeport \\ amiglo@bridgeport.edu
}

\begin{abstract}
According to Graham and Harvey (2001), an immense gap exists between capital structure theories and practice. By analyzing students' perception of capital structure theories and the differences between their opinion and that of the current CEO's and managers this paper argues that this can be partially explained by current educational practices. Educators mostly focus on one or maybe two most popular theories and students have much smaller knowledge about other theories. Secondly educational practices favor trade-off theory to asymmetric information based theories. The paper provides some suggestions regarding capital structure education and future research.
\end{abstract}

Keywords: Capital structure education, trade-off theory, pecking-order theory, shareholders-bondholders conflict, life cycle theory, flexibility theory, debt, and discipline

\section{Introduction}

The modern theory of capital structure began with the famous proposition of Modigliani and Miller (1958) that described the conditions of capital structure irrelevance. Since then, many theories of capital structure have been developed including trade off theory, pecking order theory, agency cost theory, life cycle theory and flexibility theory. After so many innovations, capital structure remains one of the most controversial and debatable issue in corporate finance. The key issues are as follows. First, an immense gap exists between theories and practice. Graham and Harvey (2001) found that less than 50\% of theoretical ideas find some support among managers. Second, there are big differences in the researchers' opinion. For example, Chirinko and Singha (2000), Leary and Roberts (2010) and Frank and Goyal (2003) claim that trade-off theory drives capital structure decisions while Shyam-Sunder and Myers (1999) and Lemmon and Zender (2008) claim that pecking-order theory drives capital structure. Third, there is difference among opinions about the direction that future work on capital structure should take. For instance, Harris and Raviv (1991) argue that asymmetric information theories of capital structure are not promising. However, the stream of research related to asymmetric information has not stopped since then. ${ }^{1}$ Furthermore, the financial crisis during 2008 and 2009 showed that corporate managers appeared to lack an understanding of the role of asymmetric information. The market for mortgage-backed securities, which many believe was at the core of financial crisis, involved asymmetric information between investors and issuers. Various scandals, such as the one involving Bernie Madoff, illustrate the depth of asymmetric information problems between firms' insiders and investors. The present paper attempts to analyze issues described above. As stated above only $50 \%$ of theories have support among managers. One can say that this gap will disappear eventually as long as the quality of existing and new theories improves over time. An alternative idea is that managers of real companies were not necessarily outstanding students in the past and that they were not always able to understand all capital structure theories taught at school. In the present paper we develop an intermediate view namely that this gap can be explained by current educational and publishing practicing existing in the field of capital structure. We feel that the gap is too big to be either disappearing naturally or being explained by the fact that capital structure managers are not able to understand existing theories.

To evaluate current educational practices we analyze 161 projects related to capital structure prepared by undergraduate and graduate students majoring in finance or in business. With the help of spreadsheet analysis students first had to find an optimal capital structure for a given company. Spreadsheet analysis is

${ }^{1}$ See, for example, Klein (2002) and Miglo (2010, 2011). 
mostly based on the trade-off between tax advantages of debt and increasing risk from debt financing. Then these students had to describe other factors that have not been taken into consideration in the spreadsheet analysis, which affect managers' decisions on company's capital structure. In the present paper we summarize students' answers and record the frequency of different theories and factors appearing in their projects. Several tables have been made to present information from the projects by cataloguing these students in different ways. Through studying these tables, we can find out students' preferences for different factors and theories of capital structure. We argue that current educational practices are such that educators mostly focus on one or maybe two most popular theories (Trade-off theory and Pecking order theory) and that students have much smaller knowledge about other theories (Agency cost, Life cycle theory, Debt and discipline and Debt and flexibility). The same is true for the majority of textbooks. Graham and Harvey (2001) argue that managers take decisions based on the current financial situation, past experiences, and informal criteria like financial flexibility and credit ratings. Educators should spend more time on teaching all these factors especially given that some of them have become quite important in theoretical research as well. Our analysis show that top students (students with good marks and who probably were more successful in learning different theories prior to the project) have much broader view about capital structure management than other students. However the views of the former are not close enough to those of managers. This shows that a potential exists for broadening and deepening capital structure education. We also feel that another reason for the gap between theory and practice is that educators focus mostly on normative aspects of theory, and not on positive aspects of theory and its applications. As a result students may be aware about existing models but are not able to apply these models in real life when they become managers. We feel that this is especially true for asymmetric information and agency cost theories which are without doubt most complicated theories technically. Educators should find a way to explain practical applications of those theories.

With regard to the gap in researchers' opinion, we argue that educational practices favor the trade-off theory to asymmetric information based theories and agency theories (perhaps because of difficulty of the latter). This should be corrected. Students who do not study hard are similar to managers in terms of mentioning trade-off theory more frequently compared to asymmetric information. Good students still like trade-off theory but also have quite a positive opinion about asymmetric information, firm flexibility or agency based theories as well. Finally in terms of debate about future development of capital structure theory, we disagree with Harris and Raviv (1991) opinion that asymmetric information theories are less promising. We feel that existing asymmetric information theories are not sufficient and this is the reason why these theories have less support than the trade-off theory among managers and students. At the same time given that the gap between theory and practice is very large, we agree with Harris and Raviv (1991) in that the door is still widely open for new theory of capital structure which can be helpful to make a bridge between managers and students which can be helpful to the future students to know more clear about capital structure. The rest of the paper is organized as follows. Section 2 describes in details the students' report. Section 3 presents a review of capital structure theories which were learned by students. These are basically all major known theories of capital structure. Section 4 describes the students' body. Section 5 presents the results of students' reports analysis and compared with managers' opinions and the conclusion is drawn in Section 6.

\section{Description of students' project report}

Students analyze a firm suggested by the instructor in the statement of assignment. Different classes deal usually with different companies. By going through the project, students should answer several questions to the company's capital structure. These questions are:

- What is the firm's current debt/equity ratio?

- Is the firm's debt/equity ratio low or high? Compare debt/equity ratio with other firms at the same industry or related industries.

- Is the firm's current debt/equity ratio explained by the firm's financial policy or by the current market conditions? Look at the firm's debt/equity ratio over the last few years.

- What is the firm's optimal capital structure according to WACC (weighted average cost of capital) approach? 
- If current debt/equity ratio different from optimal, then what factors, in your opinion, which are not taken into consideration in the spreadsheet analysis may explain this difference?

Students are encouraged to apply capital structure theories which they learn from textbooks and lectures. These theories are Pecking-Order Theory, Trade-Off Theory, Agency Cost, Flexibility and some others. Questions 1, 2 and 4 deal with financial calculations. By doing so, students can find out the company's Debt/Equity Ratio and the WACC. WACC is the expected return on all of a company's securities. It is calculated by multiplying the cost of each capital component by its proportional weight and then summing:

$W A C C=(E / V) r_{E}+(D / V) r_{D}\left(1-T_{C}\right)$

Here $\mathrm{D}$ and $\mathrm{E}$ are the market value of the firm's debt and equity, $\mathrm{V}=\mathrm{D}+\mathrm{E}$ is the firm's total market value, $\mathrm{r}_{\mathrm{D}}$ and $\mathrm{r}_{\mathrm{E}}$ are the cost of debt and equity, and $\mathrm{T}_{\mathrm{C}}$ is the marginal corporate tax rate. Students take tax into consideration, since interest paid on a firm's borrowing can be deducted from taxable income, which is the so called tax benefit. To get the optimal capital structure, students change $\mathrm{D} /(\mathrm{D}+\mathrm{E})$ ratio from $0 \%$ to $100 \%$ as hypotheses, and calculate several financial parameters for different ratios. Then they find one that has minimal WACC and respectively maximal market value for the firm. More specifically, students first calculate $\beta$ : $\beta=\left[1+\left(1-T_{C}\right) D / E\right] \beta_{0}{ }^{2}$

Then, they calculate $r_{E}$ and $r_{D}$ by the following equations:

$r_{E}=$ Current Short Term Government Rate $+\beta \times$ Risk Premium $r_{D}=$ Risk-Free Interest + Default Premium ${ }^{3}$

Then, they calculate the WACC based on the equation above, list all the WACC for different D/(D+E) ratios, and finally find the minimum WACC from the list which corresponds to the optimal capital structure. With regard to question 3, one student shows that the Oracle's D/E ratio was growing from 2005 to 2008 . With a further study, he believes a part of the reason for the growing D/E ratio is Oracle's financial policy, when the company aggressively purchased several competitors during that period and accumulated a large amount of debt. As to question 5, one student finds that the optimal debt/equity ratio (based on spreadsheet analysis) of eBay's is significantly higher than its current ratio. The student suggests that this happened because high bankruptcy cost of the industry and the needs for flexibility for future financing are not taken into consideration in the WACC approach. He holds the view that eBay invested so much money, time and effort to develop specific products, that the consequence can be very serious if it fails due to a large amount of debt. The primary reason is the company's large proportion of intellectual property which cannot be quickly converted to cash in a financial distress situation. Moreover, the e-commerce industry is still in its growth stage, the future financing requirements of the industry are unknown, therefore issuing stocks to finance today's capital needs leaves firms with more flexibility for future financing than borrowing money. Another student finds that the agency cost for Microsoft is relatively low, and he explains this phenomenon by pointing out that the biggest shareholder of Microsoft - Bill Gates - has been deeply involved in company's management. When there are fewer conflicts between managers and shareholders, there would be less agency cost.

To help with the project, all students are given a spreadsheet containing information they need - step by step - to develop their reports ${ }^{4}$. This spreadsheet is divided into following parts ${ }^{5}$ :

- Input data;

- Interest coverage ratios, rating of debt, default spreads, interest rates and probabilities of default.

${ }^{2}$ This is Ito formula. $\beta_{0}$ refers to the "unlevered" beta of the company.

${ }^{3}$ Default premium depends on the company's credit rating that ranges from AAA to D. It depends in turn on such parameters as interest coverage ratio.

4 We collect data from 2 different groups of students. One group were conducted before 2006, and the other after 2006. Data collected from both groups are similar in content, except for the construction.

5 For more details, see Appendix 1. 
- Current situation;

- Capital structure and cost of capital calculation;

- Main results.

Students are supposed to find most data about the company (earnings, expenditures, depreciation etc.) from edumarketin sight website (educational version of Standard and Poors data base) for which they had passwords provided together with their textbook (usually it was "Principles of corporate finance" by Brealey and Myers). Default spreads, risk premiums and other information for point 2 could be found on bonds online website or on Federal Reserve website. Points 3-5 represent calculations.

\section{Capital Structure Theories}

This section describes capital structure theories which students learnt in class or from a recommended textbook that for most classes was Brealey and Myers (2006) "Principles of corporate finance" of different editions. The section also discusses some challenges faced by each theory that provides a basic for further discussions about existing practices in capital structure management and education. ${ }^{6}$ As the reader will see, the trade-off theory is usually taking more time and efforts from the instructor which also reflect the situation in Brealey and Myers (2006) textbook as well as in most other books especially finance textbooks for undergraduate students.

Trade-off theory: In contrast to dividends, interest paid on debt reduces the firm's taxable income. Debt also increases the probability of bankruptcy. Trade-off theory suggests that capital structure reflects a trade-off between the tax benefits of debt and the expected costs of bankruptcy (Kraus and Litzenberger, 1973).

Consider a firm that generates a random cash flow $R$ that is uniformly distributed between 0 and $\bar{R}$. The firm faces a constant tax rate $T$ on corporate income. If the earnings are insufficient to cover the promised debt payment, $D$, there is a deadweight loss of $k R$ that is used up in the process. This loss can include direct bankruptcy costs such as fees paid to lawyers and indirect bankruptcy costs such as losses due to general lack of confidence in the firm. If earnings are large enough $(R>D)$, equity holders receive $(R-D)(1-T)$. Otherwise, they receive nothing. The market value of debt $V_{d}$ equals $\frac{\bar{R}-D}{\bar{R}} D+\frac{D}{\bar{R}} \frac{D(1-k)}{2}$. Here $\frac{\bar{R}-D}{\bar{R}}$ is the probability that $R>D$ and $\frac{D}{\bar{R}}$ is the probability of default. If $R>D$, the creditors receive $D$ and they receive on average $\frac{D(1-k)}{2}$ if the firm defaults. The market value of equity $V_{e} V_{E}$ equals $\frac{\bar{R}-D}{\bar{R}}\left(\frac{\bar{R}+D}{2}-D\right)(1-T)$. The firm's value $V$ equals

$$
V_{d}+V_{e}=\frac{\bar{R}-D}{\bar{R}} D+\frac{D}{\bar{R}} \frac{D(1-k)}{2}+\frac{\bar{R}-D}{\bar{R}}\left(\frac{\bar{R}+D}{2}-D\right)(1-T)
$$

The firm's choice of leverage is determined by maximizing $V$. The first-order condition with respect to $D$ is

$$
D=\frac{T \bar{R}}{T+1-k}
$$

Expected Bankruptcy Costs and Debt: If $k$ is higher in Equation 2, the equilibrium level of $D$ should be lower. As the expected bankruptcy costs increase, the advantages of using equity also increase. This result has several interpretations. Large firms should have more debt because they are more diversified and have lower default risk. Tangible assets suffer a smaller loss of value when firms go into distress. Hence, firms with more

${ }^{6}$ For a more detailed review of capital structure theory see, for instance, Miglo (2010). 
tangible assets, such as airplane manufacturers, should have higher leverage compared to those that have more intangible assets, such as research firms. Growth firms tend to lose more of their value than non-growth firms when they go into distress. Thus, theory predicts a negative relationship between leverage and growth. Empirical evidence by Rajan and Zingales (1995), and Frank and Goyal (2003) generally support the above predictions.

Taxes and Debt: When $T$ increases in Equation 2, debt should also increase because higher taxes lead to a greater tax advantage of using debt. Hence, firms with higher tax rates should have higher debt ratios compared to firms with lower tax rates. Inversely, firms that have substantial non-debt tax shields such as depreciation should be less likely to use debt than firms that do not have these tax shields. If tax rates increase over time, debt ratios should also increase. Debt ratios in countries where debt has a much larger tax benefit should be higher than debt ratios in countries whose debt has a lower tax benefit. The evidence, however, is mixed. Graham (2000) finds some support for tax factor. Titman and Wessels (1988) find that non-debt tax shields and the use of debt are positively correlated. According to Wright (2004), leverage in the corporate sector was remarkably stable between 1900 and 2002 despite large differences in tax rates. A survey of 392 CFOs by Graham and Harvey (2001) finds that 45 percent of the respondents agree that tax considerations play an important role in their capital structure choices.

Debt and Profitability: As suggested in Equation 2, if $\bar{R}$ increases, $D$ should also increase. Thus, more profitable firms should have more debt. Expected bankruptcy costs are lower and interest tax shields are more valuable for profitable firms. Empirical studies typically find a negative relationship between profitability and leverage (Titman and Wessels, 1988; Rajan and Zingales, 1995; Fama and French, 2002; Frank and Goyal, 2003).

Debt Conservatism: Although trade-off theory predicts that the marginal tax benefit of debt should be equal to the marginal expected bankruptcy cost, the empirical evidence is mixed. Some researchers argue that the former is greater than the latter because direct bankruptcy costs are small and the level of debt is below optimal (Graham, 2000). Others find that indirect bankruptcy costs can total as much as 25 percent to 30 percent of assets value and are thus comparable with tax benefits of debt (Molina, 2005; Almeida and Philippon, 2007). Additionally, including personal taxation in the basic model can reduce the tax advantage of debt (Green and Hollifield, 2003; Gordon and Lee, 2007) because tax rates on the return from equity such as dividends or capital gain are often reduced.

Target Debt Level: Debt changes should be dictated by the difference between current level and the level of debt predicted by Equation 2. In the recent literature, the continuous process of adjusting capital structure toward the target ratio has been called "target reversion" or "mean reversion" (Shyam-Sunder and Myers, 1999; Frank and Goyal, 2003). The evidence usually confirms mean reversion (Fama and French, 2002; Kayan and Titman, 2007). Different opinions exist about the speed of capital structure adjustments. Some researchers find that these adjustments are too slow (Fama and French, 2002) while others contend that large adjustments are costly (Altinkilic and Hansen, 2000). Deviations from the target can then be gradually removed over time (Leary and Roberts, 2010). Conducting econometric research on mean reversion remains challenging. The major difficulty is that the target debt-to-equity ratio is unobservable. Chang and Dasgupta (2007) show, for example, that even purely random financing can lead to mean reversion in simulated data. In their projects students provided their opinion about the trade-off theory. As follows from Section 2, the spreadsheet analysis takes into account taxes and also increasing risk from debt financing through changes in interest coverage ratio and changes in firm's beta. The spreadsheet ignores to some degree the magnitude of bankruptcy cost which is not directly calculated so many students expressed their opinion about that part of trade-off theory. In addition some of them made comments about the spreadsheet analysis as a whole which reflect their perception of trade-off theory in general.

Asymmetric information theories of capital structure: The key element of these theories is asymmetric information between firm's insiders and outsiders. Information asymmetries exist in almost every facet of corporate finance and complicate managers' ability to maximize firm values. Managers of good quality firms 
face the challenge of directly convincing investors about the true quality of their firm especially if this concerns future performance. As a result, investors try to incorporate indirect evidence in their valuation of firm performance by analyzing information-revealing actions including capital structure choice.

Pecking-order theory: Myers and Majluf (1984) set forth pecking order theory. Equity is dominated by internal funds in pecking order theory. Low-quality firms use equity as much as internal funds but highquality firms prefer internal funds because shares issued by the company can only be sold with discount (i.e. below their true value) because of imperfect information problems. Similarly debt dominates equity. Debt suffers from miss valuation less than equity. The same holds if the firm has available assets-in-place. Hence a "pecking order" emerges: internal funds, debt, and equity (Myers and Majluf, 1984). The empirical evidence on pecking order theory is mixed. Shyam-Sunder and Myers (1999), Lemmon and Zender (2008), and a survey of New York Stock Exchange firms by Kamath (1997) find support for pecking order while Chirinko and Singha (2000) and Leary and Roberts (2010) do not. Frank and Goyal (2003) show that the greatest support for pecking order occurs among large firms. The announcement of issuing stock drives down the stock price. Empirically, the announcements of equity issues result in significant negative stock price reactions (Masulis and Korwar, 1986; Antweiler and Frank, 2006). Good-quality firms tend to use internal funds for financing as much as possible. Because low-quality firms do not have as much profits and retained earnings as high-quality firms, they use external sources, usually debt, more frequently. This helps to explain the described above puzzle about the negative correlation between debt and profitability.

Pecking order theory predicts that a higher extent of asymmetric information reduces the incentive to issue equity. The evidence, however, is ambiguous. D'Mello and Ferris (2000) and Bharath, Pasquariello, and Wu (2008) support the prediction that pecking order theory is more likely to hold when the extent of asymmetric information is large. Choe, Masulis, and Nanda (1993) find that equity issues are more frequent when the economy is doing well and information asymmetry is low. Yet, Frank and Goyal (2003) find the greatest support for pecking order theory among large firms that are expected to face the least severe adverse selection problems because they receive better coverage by equity analysts. In the research students gave their insights regarding this theory and whether the company had practiced the pecking order theory as the base to use internal funds-debt over equity. The students gave their insights about why firms have a preference towards using internal funds over other sources of funds as supported by the pecking order theory.

Signaling: In the pecking order model, good quality firms have to use internal funds to avoid adverse selection problems and losing value. These firms cannot signal their quality by changing their capital structure. In signaling theory capital structure serves as a signal of private information (Ross, 1977). The main prediction of this theory is that the market reaction on debt issues (more generally, on leverageincreasing transactions such as issuing convertible debt, repurchasing shares, and debt for equity swaps) is positive. Similarly, the market reaction on equity issues (or leverage-decreasing transactions) is negative. Leland and Pyle (1977) obtain the same results by using managerial risk-aversion instead of a bankruptcy penalty. A negative share price reaction on the announcement of equity issues is usually consistent with empirical evidence, as discussed in the previous section (similar for leverage-decreasing transactions). Evidence on the positive market reaction on leverage-increasing transactions (with the exception of debt issues) also supports signaling theory (Masulis, 1980; Antweiler and Frank, 2006; Baker, Powell, and Veit, 2003). The evidence on the announcement of debt issues does not support signaling theories. Eckbo (1986) as well as Antweiler and Frank (2006) find insignificant changes in stock prices in response to straight corporate debt issues. If a separating equilibrium exists, high-quality firms issue debt and low-quality firms issue equity. The empirical prediction is that firm value (or profitability) and the debt-to-equity ratio is positively related. The evidence, however, is ambiguous. Most empirical studies report a negative relationship between leverage and profitability as discussed earlier. In a similar spirit, some studies document the superior absolute performance of equity-issuing firms before and immediately after the issue (Jain and Kini, 1994; Loughran and Ritter, 1997). Several studies examine long-term firm performance following capital structure changes. Shah (1994) reports that business risk falls after leverage-increasing exchange offers but rises after leverage-decreasing exchange offers. Jain and Kini (1994), Mikkelson, Partch, and Shah (1997), and Loughran and Ritter (1997) document the long-run operating underperformance of equity issuing firms 
compared to non-issuing firms.

Agency cost-based theories of capital structure: Agency costs arise because managers do not necessarily act in the best interests of shareholders who also may not act in the best interests of creditors. Including agency costs in the basic model can help to explain some problems of trade-off theory discussed above such as debt conservatism.

Shareholders-creditors conflict: If an investment yields large returns, equity holders capture most of the gains. If, however, the investment fails, debt holders bear the consequences. As a result, equity holders may benefit from investing in highly risky projects, even if the projects are value decreasing. Jensen and Meckling (1976) call this the "asset substitution effect". Debt holders can correctly anticipate equity holders' future behavior. This leads to a decrease in the value of debt and reduces the incentive to issue debt. Myers (1977) observes that when firms are likely to go bankrupt in the near future, equity holders may have no incentive to contribute new capital to invest in value-increasing projects. Equity holders bear the entire cost of the investment, but the returns from the investment may be captured mainly by the debt holders ("debt overhang"). On the other hand, some agency theories favor higher debt. For example, Jensen (1986) argues that debt improves the discipline of an entrenched manager (so called "debt and discipline" theory). The evidence confirms that firms use leverage as a disciplinary device for managers. For example, firms reduced their leverage after the Sarbanes-Oxley Act (2004) that required more reliable financial information and hence reduced the extent of agency problems (Bertus, Jahera, and Yost, 2008). Jensen and Meckling (1976) contend that choosing debt instead of equity allows for the insiders' fraction of equity to remain high and thus improves their incentive to work in the interests of shareholders. Malmendier, Tate, and Yan (2005) and Hackbarth (2008) present behavioral models in which an overconfident manager chooses higher debt levels than does a rational manager. The overall effect of agency problems on debt level is difficult to quantify. Additionally, the general importance of the asset substitution problem is under debate (Parrino and Weisbach, 1999). In their survey of chief financial officers (CFOs), Graham and Harvey (2001) find this problem unimportant.

Flexibility theory of capital structure and life cycle theory of capital structure: Firms in the development stage have little favorable track record (i.e., credit ratings) of borrowing (Diamond, 1991) and are most likely to be turned down for credit when they need it the most. Thus, firms in the development stage that have little financial flexibility will abstain from issuing risky debt and will instead issue equity. Firms in the growth stage begin generating positive earnings and have more financial flexibility than developing firms. Accordingly, these firms rely on debt financing to fund their growth options as they face less financing constraints and as they expect to repay their debt with growing future earnings. Thus, firms in the growth stage tend to have high leverage ratios. Firms in the maturity stage generate large cash flows from assets already in place and rely mainly on self-financing for their investment needs. They are more concerned with servicing debt they raised during the growth stage rather than they are with issuing more debt because they expect future cash flows to deteriorate. Accordingly, mature firms prefer to maintain moderate debt levels. Flexibility theory finds some support in empirical studies (Byoun, 2008) and managers' surveys (Graham and Harvey, 2001). This theory helps to explain why small and risky firms issue equity and why these firms do not follow pecking-order theory. Gamba and Triantis (2008) develop a theoretical model that analyzes optimal capital structure policy for a firm that values flexibility in the presence of personal taxes and transaction costs. The importance of financial flexibility as compared to major theories of capital structure remains an open question. More work that compares flexibility theory with other theories is expected. Also it was noted that many young firms especially venture firms do not issue common equity but rather convertible preferred equity which resembles debt more than equity. Life cycle theory of capital structure argues that besides financial flexibility there are other factors which can explain financing patterns of firms in different stages of their development (Damodaran, 2003). Start-up firms do not have much profit, so the tax advantage of debt is not as important as for a mature firm. The start-up firms do not require incentives for managers since there is no large separation between ownership and management like in the case of big public corporations. This leads to the idea that mature firms value debt more compared to start-up firms. To what extent the life cycle theory represents a separate theory of capital structure rather than a combination of arguments from other 
theories remains an open question. Thus in this part of the research students were required to apply the Life Cycle theory in their report and find out if there was any practical application of the propositions.

Several major conclusions emerge from the development of capital structure theory over the past 20 years. First, researchers have extensively tested trade-off and pecking order theories. Taken separately, these theories cannot explain certain important facts about capital structure. In the future, financial economists need to continue developing dynamic versions of each theory or to develop new models that incorporate both trade-off and pecking order ideas. Second, a popular line of inquiry has emerged based on surveys of managers about their capital structure decisions. For example, Graham and Harvey (2001) report a large gap between theory and practice. Third, signaling theory of capital structure lacks empirical support regarding some of its core predictions. However, several new theories have emerged that contradict the notion of signaling quality through debt issuance. More research may be required to create new models that can compete with trade-off and pecking order theories. During the course of their finance studies the students learned each of the theories described above in the chapter. The amount of time instructors spend on teaching each particular theory and its depth relative to other theories correspond approximately to the presentation in this chapter. The reader can see a slight dominance of trade-off theory, for example, in terms of the volume of material, the presence of quantitative part and a number of implications.

Student Body: The students' body consists of undergraduate and graduate students of different American and Canadian universities who study for Finance or Business majors. These students have career aspiration of being a part of financial sector and related fields. Almost 90 percent of the students have already taken statistics, mathematics and calculus classes and are familiar with using spreadsheet. ${ }^{7}$ Prior to the work on Capital Structure project, the students learned the key financial concepts, such as the Time Value of Money, the concept of Cost of Capital, the basics of valuation and different theories of Capital Structure. The students sample covered a total of 161 students. 39 students are from American universities and 122 students are from Canadian universities. All students had to find out the companies' optimal D/E ratios, and use different capital structure theories to explain companies' current capital structure strategies. We then reviewed students' results and suggestions. We categorized students into four groups according to their level of grades. The first group contains 32 students with the grades from 90 to 100 . The opinions of this group were considered as most important while making the conclusions about the report since this group is excellent in analyzing company's capital structure. The students from this group thoroughly understood every theory and proposition of the Capital Structure learned during their class, thus they are considered to have no difficulty in evaluating which theory of the Capital Structure the company has applied. Also, this group of students provided effective recommendations about the capital structure of the firm. The second group contains 66 students with the grades from 80 to 89. A general observation of this group showed that, most students can thoroughly understand the theories and propositions of the Capital Structure taught in the class, leaving some few exceptions. About fifty percent of the students in this group provided their recommendations regarding the capital structure of the firms. The third group contains 47 students with the grade from 70 to 79 . Among them, only one third of the students can understand all the theories and propositions of the Capital Structure. The rest can only understand some of these theories and propositions. As a result, they could not analyze the correct capital structures of the firm. The forth and the last group contains students with the grades below 70 . Most of the students could not thoroughly understand the theories of Capital Structure as a result their reports did not contain reasonable explanations of companies' motivation on capital decisions. Their preferences of Capital Structure theories were vague. Our primary purpose is to get feedbacks from the students of different levels, and to help business students to better understand the capital structure theory. Information that we collected is new and very unique. Our sample contains both graduate students and undergraduate students, and students of different levels.

7 B.S Program $\quad$ details $\quad$ (2010). $\quad$ Retrieved $\quad$ October $\quad 21, \quad$ from

http://www.bridgeport.edu/academics/undergraduate/businessadminbs/default.aspx 
Table 1: Student's body

\begin{tabular}{lllll}
\hline \multirow{2}{*}{ Gender } & Female & $\mathbf{\%}$ & Male & $\mathbf{\%}$ \\
\cline { 2 - 5 } Degree & 59 & $37 \%$ & 102 & $63 \%$ \\
& Undergraduate & $\%$ & Graduate & $\%$ \\
\multirow{2}{*}{ Student Nationality } & 122 & $76 \%$ & 39 & $24 \%$ \\
\multirow{2}{*}{ University Location } & Asian & $\%$ & Others & $\%$ \\
& 51 & $32 \%$ & 110 & $68 \%$ \\
& Canada & $\%$ & US & $\%$ \\
\hline
\end{tabular}

From Table 1 we can see that from the total of 161 students 59 are female (37\%) and 102 are male (63\%). Also, we find that 51 students (32\%) have Asian origin and 110 have non-Asian origin. As we discuss in next chapter some individual attributes affect students' results. For example, female students seem to have more theoretical knowledge than male students while male students have more practical experience. Also female students are relatively more conservative than males. A risk-loving student may prefer to keep high debt ratio to seek for high risk and higher benefits. So their responses are often very different from what they learn in school. Students of Asian origin tend to have slightly better mathematical skills than average students from other countries. It may influence the level of understanding of theories which require better technical knowledge. Also note that 98 students ( $61 \%$ of total population) had grades from $80 \%$ to $100 \%$, which means that most of the respondents do have basic understanding of capital structure theory and provide a reasonable feedback. In the next chapter we discuss the results of the students' projects with regard to capital structure theories discussed previously.

\section{Results from the Samples}

We divided all answers into following categories.

- Student agrees with the theory and thinks it can explain the firm's current capital structure situation

- Student supports the theory but feels that managers do not use it.

- Student supports the theory but feels that it cannot be applied for that specific firm.

- Student does not support the theory but thinks that managers mistakenly use this theory.

- Student does not support the theory and thinks it does not apply for the company.

- Student demonstrates misunderstanding of the theory.

- Student has no opinion.

Table 2: Student's perception of capital structure theories ${ }^{8}$

\begin{tabular}{|c|c|c|c|c|c|c|c|}
\hline & Supporsused & Supporstheory $n \pi$ Applicablo w Arm & Supporshowused by managars & Doses not suppontused & Doses norgupportho used & Misundersandiling & Mo colirion \\
\hline $\begin{array}{l}\text { Trado of } \\
\text { Theory }\end{array}$ & 34 & 23 & 69 & 1 & 9 & 3 & 22 \\
\hline $\begin{array}{c}\text { Peoking orosir } \\
\text { Theory }\end{array}$ & 46 & 9 & 7 & 0 & 0 & 3 & 96 \\
\hline $\begin{array}{l}\text { Asymmartc } \\
\text { Irfromation }\end{array}$ & 67 & 17 & 27 & 4 & 5 & 10 & 31 \\
\hline Agsency $\cos \Omega$ & 58 & 31 & 21 & 2 & 4 & 15 & 30 \\
\hline $\begin{array}{l}\text { Dabrand } \\
\text { Dsciplinge }\end{array}$ & 37 & 47 & 30 & 0 & 1 & 2 & 44 \\
\hline $\begin{array}{l}\text { Lin Gollo } \\
\text { Theory }\end{array}$ & 76 & 12 & 10 & 1 & 2 & 2 & 58 \\
\hline $\begin{array}{l}\text { Prure } \\
\text { Flaxiblilly }\end{array}$ & 76 & 11 & 7 & 0 & 2 & 3 & 62 \\
\hline
\end{tabular}

${ }^{8}$ For detailed statistics see Appendix 2. 
The results are presented in Table 2. We first consider theories that have most support among students. These are trade-off theory (126 students support theory including those who think the theory is used by the firm or it is not applicable or it is not used by managers), asymmetric information (111), agency cost (110) and flexibility (94). Numbers are quite similar for advanced students. This should be similar to managers' survey. However, when we compare these numbers with managers' opinion we find that managers mostly support flexibility idea. About 59.38\% managers indicated financial flexibility as an important or very important factor of capital structure. The firms' credit rating is another vital factor for managers. For making the students' result objective, we checked every student's paper. Based on their answers, we found some students did not have clear opinions or no opinions, so we put them into the no opinion category. Some answers demonstrated the misunderstanding of capital structure theories. We put them into the misunderstanding category. As follows from Table 2, the trade-off theory only has 3 students misunderstanding and 22 students with no opinion. Both numbers are the smallest ones among all theories. The reason, we believe, is that the trade-off theory is the most popular capital structure theory. Not only textbooks, but also teachers spend most time on this theory. Pecking order theory is a popular theory as well. However, there are 96 students with no opinion about this theory, which is the most among all theories. This is probably because the pecking order theory is more complex than the trade-off theory. The pecking order theory, for example, does not have a formula, like the trade-off theory. When we compare managers and students, we eliminate misunderstanding and no opinion categories, to make the results more objective and reasonable. It is very hard to eliminate the subjective bias completely. However, we used different grade levels students' answers, divided all answers into seven different categories, and considered the individual attributes to reduce the subjective bias problem.

Trade-off Theory - from 161 students, 34 support the trade-off theory and believe it's been used by managers of the company. There are also 69 students who support the theory, but think that it is not used by managers. 23 students support the trade-off theory and thought it was not applicable to company's capital structure. The main reason is that most companies in the project operate in high-tech industries and they need to maintain a relatively low debt ratio to be more flexible in future investments. 22 students have no opinion about trade-off theory. 3 students misunderstand it and 10 students do not support the usage of trade-off theory. Also, 55 students suggest the managers should adjust capital structure by increasing debt ratio. As the company grows, profits increase and separation between ownership and management becomes more important. Under this situation, managers should take advantage of debt. By increasing debt ratio, company would gain more benefit from tax shield and it will be less risk of managers' complacency. The trade-off theory is the most supported theory among students, but, at the same time, has the largest number of students who think that managers do not use it. Most individual attributes do not affect the above conclusions significantly. However, $90 \%$ (35 in total) of graduate students support the trade-off theory, while only $75 \%$ (91 in totals) of undergraduate students support the theory. The difference is about $15 \%$. We think the reason is that graduate students' calculation ability is better than undergraduate students. Trade-off theory requires much more calculations than other theories. Because both groups have very high level of support for the trade-off theory, we do not believe that the difference influences significantly our overall conclusions. Apparently managers have a similar opinion about trade-off theory, but there are a lot of differences in details. First, managers think the tax shield is moderately important when they made capital structure decisions. The tax advantage of debt is the forth important factor (45\% of managers support this idea) that affects the amount of debt for firms. It should be noted however that even the first factor (financial flexibility) has support of only $59 \%$ of managers.

The main reason of the low percent is that the small and start-up companies do not use tax shield because of low profits. Also, managers do not care about bankruptcy costs (only 21\% managers support it). However, managers are concerned about credit rating and earnings and cash flow volatility when making capital structure decisions. These two factors are related to bankruptcy cost. Managers like credit rating idea because it affects directly the company ability to borrow money. They do not really look at the link between credit rating and expected bankruptcy costs. 50 students thought that the cost of financial distress theory is relevant to companies' capital structure since these companies were making a lot of profits every year and they do not want to increase the risk of bankruptcy. Therefore, these companies keep a low debt ratio. Overall we think that the trade-off theory and its education should be more focused on its practical aspects. In 
particular, students and managers should clearly understand how to calculate the expected bankruptcy costs. If managers would have more profound understanding of expected bankruptcy cost concept they would understand that there are other factors besides credit rating that affect expected bankruptcy cost. Although only $10 \%$ of firms have strict target ratio, $34 \%$ have somewhat tight target and $37 \%$ have flexible target. The trade-off theory believes firms have an optimal ratio, but firms are operating in a dynamic environment. Therefore, the target ratio can be flexible. We think that much more time in education should be spent on the dynamic version of trade-off theory although that can be challenging because the new dominant direction here has not yet emerged. Secondly we feel that another line of research should analyze why in practice taxes do not seem to be important for capital structure (less than 50\% of managers support the idea despite its simplicity). Thirdly, the textbook should add methods to calculate expected bankruptcy cost. Otherwise students do not know how to judge the benefits from reducing the cost of bankruptcy.

Agency Cost - from 161 students, 58 support the Agency Cost theory and believe it's been used by managers of the company. 31 support the theory though they do not think it is applicable to the company. Most of them thought that there was no agency cost existing between managers and stockholders for those companies because the latter did not have a separation of management and ownership. We found that most of these 31 students are from Asia. We think that the reason for why students of Asian origin may not recognize potential agency problems is twofold. On one hand agency theories of capital structure were developed later than other theories, they are still to be popularized in countries such as China and so we think these students did not hear much about these problems during their previous studies. Secondly, most of Asian firms traditionally did not have a separation of management and ownership. We think that educators (especially in classes with a significant fraction of students of Asian origin) should remember about this point and should find cardinally new ways of teaching agency problems to them. 21 students support the theory however they think that the theory is not being used by managers. The main reason is that managers do not want to be disturbed by creditors when they invest money in some risky projects (assets substitution problem). 6 students do not support agency cost theory and 30 students have no opinion about it. 15 students demonstrated a misunderstanding of agency cost theory. Last two numbers are the largest ones among all theories. We think that educators need to give students more information about agency cost theory to make it less confusing. One problem related to agency cost is that it is difficult to have a formula similar to the trade-off theory. This makes agency cost theory difficult to apply as a tool used in the real capital structure decisions. Managers do not support the asset substitution idea. In addition, there is little evidence that executives issue short-term debt to minimize asset substitution problems. Also there is little evidence that firms discipline managers by issuing debt. However, we think that managers' opinion with regard to agency cost importance in debt policy can be biased since it may indirectly provide (in managers' view) a signal about their wrong choice of investment projects etc. A suggestion for future surveys is to not ask direct questions about agency cost but rather offer managers a choice among different practical situations which will implicitly include scenarios of agency costs (not necessarily all of them). Perhaps such a survey can reveal more information about true managers' attitude toward agency cost. One can also try to survey shareholders or banking employees about the importance of this aspect of financing. Nevertheless we are convinced that teaching agency cost should go far beyond traditional approach where teachers (and textbooks) just provide an intuitive idea such as for example that absence of debt can make managers lazy or too much debt creates an asset substitution problem. Professors should necessarily incorporate practical cases in their lectures when teaching these topics.

Asymmetric Information - from 161 students, 67 support the Asymmetric information theory and believe it's been used by managers of the company. 17 support the theory though they do not think it is applicable to the company. 27 students support the theory however they think that the theory is not being used by managers. 31 students have no opinion about Asymmetric information theory. 10 students had misunderstandings and 9 students do not support use of Asymmetric information theory. The main idea among students who support asymmetric information theory is that the companies are not willing to send an adverse signal to outsiders when issuing securities. For example, many companies maintain a very low debt ratio in order to let the investors know that their company had a lot of internal funds to support the companies' daily operation and investments. Managers' opinion is partly consistent with this idea. They are concerned about stock undervaluation when choosing capital structure (especially large companies). 
However as concluded by Graham and Harvey (2001) they do not necessarily relate this concern to informational asymmetry problem. This is similar to expected bankruptcy cost idea. Managers do not understand bankruptcy costs while they affect managers' decisions indirectly (through other factors). Our opinion about asymmetric information theory is very similar to considered above agency theory. A relatively high number of students misunderstand the theory. The theory is quite challenging technically though it is strongly supported by good and very good students. We believe that educators should find ways of teaching asymmetric information theory more effectively. At the same time they need to teach how to apply this theory in practice. When educators will be able to teach theory along with how to apply the theory in practice, students and managers will have more confidence towards the theory. Currently educators teaching asymmetric information focus largely on ideas.

Debt and Discipline - from 161 students, 37 support the debt and discipline theory and believe it's been used by managers of the company. Most students (47 students) support the theory though they do not think it is applicable to the company. This is because most companies belong to high-tech industries and have low debt ratio because financial flexibility is very important. 30 students support the theory however they think that the theory is not used by managers. 44 students have no opinion about debt and discipline theory. 15 students demonstrated misunderstandings of this theory. Only one student does not support the theory. He explains that the company is earning a lot of profit and maintaining a very low debt ratio would not make managers complacent. The fact that students support debt and discipline theory is not consistent with managers' opinion. Our thoughts about managers' opinion here are similar to those regarding asset substitution problem described above. In other words, managers' opinion with regard to debt and discipline idea can be biased since it may indirectly provide (in managers' view) a signal about their complacency etc. Since students support debt and discipline idea we are not convinced that this idea should be excluded from capital structure education. It seems like teachers spend much more time on teaching traditional agency cost of debt such as asset substitution problem and spend much less time on teaching debt and discipline.

Firm Flexibility - from 161 students, 76 support the firm flexibility theory and believe it's been used by managers of the company. 11 support the theory though they do not think it is applicable to the company. 7 students support the theory however they think that the theory is not being used by managers. 62 students have no opinion about Firm Flexibility theory. 3 students misunderstand the idea and 1 student does not support it. Among 94 students that support the firm flexibility theory, there are 50 female students, which constitute $85 \%$ of the total number of female students. Also there are 44 male students, which is only $43 \%$ of the total number of male students. The main reason, we believe, is that female students are more conservative than male. If small and risky firms issue debt instead of issuing equity, they would face much more bankruptcy risk. Female students are not comfortable with increasing bankruptcy risk. Among all the theories, Firm Flexibility gains the most support from managers' side (59\%). It is very important that every firm keeps reasonable financial flexibility for future projects. However, the level of flexibility differs across industries and business growth stages. 38 students support future flexibility theory and its influence on company's capital structure. Among these 38 students, there are 16 students who think that this is relevant to company's capital structure. The main reason they gave out is that the companies like Yahoo, Amazon, Microsoft, Google, EBay and Apple are all belong to high-tech industry. These companies are operating in high tech growing industries. Thus they have to prepare for future changes by maintaining a low debt ratio. This idea is fully consistent with managers' opinion. As to firms' growth stages, companies in development stage should keep larger flexibility than those who are in more mature stage, because young firms should be more prepared for future expansion. On education side teachers should spend more time on teaching flexibility theory mostly because quite high number of students (62) does not have any opinion about this theory and because managers really support this theory. We think that this is mostly because textbooks do not explain this theory with the same passion and effort as standard theories such as trade-off theory and pecking-order theory. A challenge for professors and textbooks here is that the flexibility theory of capital structure does not seem to be as rigorous as the main theories. Often it is presented just as a "nice" idea. Furthermore the flexibility idea often is taught as a part of pecking -order theory since the latter also recommends avoiding debt financing in favor of internal financing. The motifs however are different in both cases. So our feeling is that teaching only theory results and implications without really focusing on assumptions and fundamental ideas behind each theory has drawbacks especially in the long term. In the end, it leads to students' confusion 
and in it makes difficult real life decisions for managers. In real life managers should be able to make adjustments to the theories they learn in school. However, making such adjustments without understanding the essential part of each idea can lead to wrong interpretations of what can happen in reality and consequently to wrong decisions. To summarize, teaching of firm flexibility theory should be improved. And researchers should discover why managers prefer flexibility over main theories.

Life Cycle Theory - from 161 students, 76 support the Life Cycle theory and believe it's been used by managers of the company. 12 support the theory though they do not think it is applicable to the company. 10 students support the theory however they think that the theory is not being used by managers. 58 students have no opinion about Life Cycle theory. 2 students misunderstand the life cycle theory. In best students group, a lot of students think managers do not use this theory enough. Generally speaking, however, students support it and think it has been used. The data shows that the managers do not support and do not use the life cycle theory. Also the data shows that there is no difference between start-up and mature firms in terms of this theory importance for them. However, according to the theory, the results from start-up companies and mature companies should have significant differences. It was mentioned in previous chapters that in recent years some new research emerged regarding life cycle theory. It is not clear at this point though whether this theory should be taught as a separate theory or as a combination of arguments from other theories (mostly trade-off theory and agency).

Pecking Order Theory - from 161 students, 46 support the pecking order theory and believe it's been used by managers of the company. 9 support the theory though they do not think it is applicable to the company. 7 students support the theory however they think that the theory is not being used by managers. Those students who considered the pecking order theory to be relevant mostly argue that the managers prefer to use internal funds over external financing because there is less risk for company to use internal funds. 3 students misunderstood the pecking-order theory. 96 students $(60 \%)$ have not mentioned this theory in their reports that is quite surprising. This can be explained by theory's difficulty. Among 96 students who have not mentioned the pecking order theory, there are 79 undergraduate students, which are $65 \%$ of total number of undergraduate students, and there are 17 graduate students, which is $44 \%$ of total number of graduate students. We believe that compared to undergraduate students, graduate students may have some work experiences or internship experiences to help them to understand this theory. Managers' opinion is partly consistent with theory. They prefer internal funds and often they are concerned about stock undervaluation when choosing capital structure (especially large companies). However, as concluded by Graham and Harvey (2001), they do not necessarily relate this concern to informational asymmetry problem. For example, managers in high-tech industry or companies in development stage prefer to use internal funds when raising capital due to concerns of maximizing cash flow in the future. That can be interpreted as a misunderstanding of the modern concept of firm objective which is firm's value maximization. We feel that in order to get more appreciation from students and managers, pecking-order theory should be taught in more practical way. Teachers should be able to explain how this theory can be used when making practical decisions. There is no doubt that this theory has interesting insights but its applications in real world should be taught better.

\section{Conclusion}

Graham and Harvey (2001) argue that managers take decisions based on the current financial situation, and such criteria as financial flexibility and credit ratings. Educators should spend more time on teaching all these factors especially given that some of them have become quite important in theoretical research as well. Another reason for the gap between theory and practice is that educators focus mostly on normative aspects of theory, and not on positive aspects of theory and its applications. As a result students may be aware about existing models but are not able to apply these models in real life when they become managers. We feel that this is especially true for asymmetric information and agency cost theories which are without doubt most complicated theories technically. Educators should find a way to explain practical applications of those theories. With regard to the gap in researchers' opinion, educational practices favor the trade-off theory to asymmetric information based theories and agency theories. This should be corrected. Students who do not study hard are similar to managers in terms of mentioning trade-off theory more frequently compared to asymmetric information. Good students still like trade-off theory but also have quite a positive opinion about 
asymmetric information, firm flexibility or agency based theories as well. In terms of debate about future development of capital structure theory, we feel that existing asymmetric information theories are not sufficient and this is the reason why these theories have less support than the trade-off theory among managers and students. At the same time given that the gap between theory and practice is very large, so the door is still widely open for new theory of capital structure which can be helpful to make a bridge between managers and students which can be helpful to the future students to know more clear about capital structure.

\section{References}

Almeida, H. \& Philippon, T. (2007). The Risk-adjusted Cost of Financial Distress. Journal of Finance, 62(6), $2557-2586$.

Altinkilic, O. \& Hansen, R. (2000). Are There Economies of Scale in Underwriting Fees? Evidence of Rising External Financing Costs. Review of Financial Studies, 13(1), 191-218.

Antweiler, W. \& Frank, M. Z. (2006). Do U.S. Stock Markets Typically Overreact to Corporate News Stories? Working Paper, University of British Columbia and University of Minnesota.

Baker, K. H., Powell, G. E. \& Veit, E. T. (2003). Why Companies Use Open-Market Repurchases: A Managerial Perspective. Quarterly Review of Economics and Finance, 43(3), 483-504.

Baskin, J. (1989). An empirical investigation of the pecking order hypothesis. City University of New York.

Bertus, M., Jahera Jr., J. S. \& Yost, K. (2008). Capital Structure, Corporate Governance, and the Effect of Sarbanes-Oxley, Corporate Ownership and Control.

Bharath, S., Pasquariello, P. \& Wu, G. (2008). Does Asymmetric Information Drive Capital Structure Decisions? Review of Financial Studies, 22(8), 3211-3243.

Brealey, R. A., Stewart, C. \& Myers, F. A. (2006). Principles of Corporate Finance (8 $8^{\text {th }}$ Ed.) NY: McGrawHill/Irwin

B.S. Program details. (2010). Retrieved October 21, 2010 from http://www.bridgeport.edu/academics/undergraduate/businessadminbs/default.aspx

Byoun, S. (2008). Financial Flexibility and Capital Structure Decision, working paper. Available at SSRN: http://ssrn.com/abstract $=1108850$

Campbell, D. E. \& Kelly, J. S. (2010). Social Choice and Economic Theory. Retrieved September 18, 2010 from http://www.jstor.org/pss/2117871

Chang, X. \& Dasgupta, S. (2007). Target Behavior and Financing: How Conclusive Is the Evidence. Journal of Finance, 64(4), 1767-1796.

Chirinko, R. \& Singha, A. (2000). Testing Static Trade-off Against Pecking Order Models of Capital Structure: A Critical Comment. Journal of Financial Economics, 58(3), 417-425.

Choe, H., Masulis, R. \& Nanda, V. (1993). Common Stock Offerings across the Business Cycle. Journal of Empirical Finance, 1(1), 1-29.

Damodaran, A. (2003). Corporate Finance: Theory and Practice (Wiley Series in Finance).

Diamond, D. W. (1991). Monitoring and Reputation: The Choice between Bank Loans and Directly Placed Debt. Journal of Political Economy, 99(2), 689-721.

D'Mello, R. \& Ferris, S. P. (2000). The Information Effects of Analyst Activity at the Announcement of New Equity Issues. Financial Management, 29(1), 78-95.

Eckbo, B. E. (1986). Valuation Effects of Corporate Debt Offerings. Journal of Financial Economics, 15(1), 119151.

Financesholar.com. Modigliani \& Miller (M\&M Propositions I\&II) - Capital Structure of Corporations. Retrieved October 4, 2010, from http://www.financescholar.com/modigliani-millerpropositions.html

Fama, E. \& French, R. K. (2002). Testing Trade-off and Pecking Order Predictions about Dividends and Debt. Review of Financial Studies, 15(1), 1-33.

Frank, M. Z. \& Goyal, V. K. (2003). Testing the pecking order theory of Capital Structure. Journal of Financial Economics, 67(2), 217-248

Gamba, A. \& Triantis, A. J. (2008). The Value of Financial Flexibility. Journal of Finance, Forthcoming.

Gordon, R. \& Lee, Y.(2007). Interest Rates, Taxes and Corporate Financial Policies. National Tax Journal, 60(1), 65-84. 
Graham, J. R. (2000). How Big Are the Tax Benefits of Debt? Journal of Finance, 55(5), 1901-1941.

Graham, J. R. \& Harvey, C. R. (2001). The theory and practice of corporate finance: Evidence from the field. Journal of Financial Economics, 60 (2-3), 187-243.

Green, R. \& Hollifield, B. (2003). The Personal-tax Advantages of Equity. Journal of Financial Economics, 67(2), 175-216.

Gulflink Survey and sample description (n.d). Retrieved November 8, 2010 from http://www.gulflink.osd.mil/library/randrep/pesticides_survey/mr1018.12.chap2.html

Hackbarth, D. (2008). Managerial Traits and Capital Structure Decisions. Journal of Financial and Quantitative Analysis, 43(4), 843-881.

Harris, M. \& Raviv, A. (1991). The Theory of Capital Structure. The Journal of Finance, 46(1), 297-355

Investopedia, Weighted Average cost of capital. Retrieved October 11, 2010 from http://www.investopedia.com/terms/w/wacc.asp

Jain, B. \& Kini, O. (1994). The Post-Issue Operating Performance of IPO Firms. Journal of Finance, 49(5), 16991726.

Jensen, M. C. (1986). Agency Costs of Free Cash Flow, Corporate Finance, and Takeovers. American Economic Review, 76(2), 323-329.

Jensen, M. C. \& Meckling, W. H. (1976). Theory of the Firm: Managerial Behavior, Agency Costs and Ownership Structure. Journal of Financial Economics, 3(4), 305-360.

Kamath, R. (1997). Long-term Financing Decisions: Views and Practices of Financial Managers of NYSE Firms. Financial Review, 32(2), 331-356.

Kayhan, A. \& Titman, S. (2007). Firms' Histories and Their Capital Structures. Journal of Financial Economics, 83(1), 1-32.

Klein, L. S., O'Brien, T. J. \& Peters, S. R. (2002). Debt vs. Equity and Asymmetric Information: A Review. The Financial Review, 37(3), 317-350.

Kraus, A. \& Litzenberger, R. H. (1973). A State-preference Model of Optimal Financial Leverage. Journal of Finance, 28(4), 911-922.

Leary, M. T. \& Roberts, M. R. (2010). The Pecking Order, Debt Capacity, and Information Asymmetry. Journal of Financial Economics, 95(6), 332-355.

Leland, H. E. \& Pyle, D. H. (1977). Information Asymmetries, Financial Structure, and Financial Intermediation. Journal of Finance, 32(2), 371-378.

Lemmon, M. L. \& Zender, J. F. (2008). Debt Capacity and Tests of Capital Structure Theories, Working Paper, University of Utah and University of Colorado.

Loughran, T. \& Ritter, J. R. (1997). The Operating Performance of Firms Conducting Seasoned Equity Offerings. Journal of Finance, 52(5), 1823-1850.

Malmendier, U., Tate, G. A. \& Yan, J. (2005). Corporate Financial Policies with Overconfident Managers, Working Paper, Stanford University and University of Pennsylvania.

Masulis, R. W. (1980). The Effects of Capital Structure Change on Security Prices: A Study of Exchange Offers. Journal of Financial Economics, 8(2), 139-177.

Masulis, R. \& Korwar, A. (1986). Seasoned Equity Offerings: An Empirical Investigation. Journal of Financial Economics, 15(1), 91-118.

Mello, A. S. \& Parsons, J. E. (1992). Measuring the Agency cost of debt. Journal of Finance, 47(5), 1887-904.

Miglo, A. (2011). Trade-off, pecking order, signaling and market timing models. Ch. 10 In Capital Structure and Corporate Financing Decisions, Ed. Baker K., and G. Martin. Wiley.

Miglo, A. (2010). Capital structure theory: where do we stand after crisis? University of Bridgeport working paper.

Mikkelson, W. H., Partch, M. M. \& Shah, K. (1997). Ownership and Operating Performance of Companies that Go Public. Journal of Financial Economics, 44(2), 281-307.

Modigliani, F. \& Miller, M. H. (1958). The Cost of Capital, Corporate Finance and the Theory of Investment. American Economic Review, 48(3), 261-297.

Molina, C. A. (2005). Are Firms Underleveraged? An Examination of the Effect of Leverage on Default Probabilities. Journal of Finance, 60(3), 1427-1459.

Myers, S. C. (1977). Determinants of Corporate Borrowing. Journal of Financial Economics, 5(2), 147-175.

Myers, S. C. \& Majluf, N. S. (1984). Corporate Financing and Investment Decisions When Firms Have Information That Investors Do Not Have. Journal of Financial Economics, 13(2), 187-221. 
Parrino, R. \& Weisbach, M. S. (1999). Measuring Investment Distortions Arising from Stockholder-bondholder Conflicts. Journal of Financial Economics, 53(1), 3-42.

Rajan, R. \& Zingales, L. (1995). What Do We Know about Capital Structure: Some Evidence from International Data, Journal of Finance, 50(5), 1421-1460.

Ross, S. A. (1977). The Determination of Financial Structure: The Incentive Signaling Approach. Bell Journal of Economics, 8(1), 23-40.

Sarbanes-Oxley, A. (2004). Available at http://www.gpo.gov/fdsys/pkg/PLAW-107publ204/pdf/PLAW107publ204.pdf.

Shah, K. (1994). The Nature of Information Conveyed by Pure Capital Structure Changes. Journal of Financial Economics, 36(2), 89-126.

Shyam-Sunder, L. \& Myers, S. C. (1999). Testing Static Tradeoff against Pecking Order Models of Capital Structure. Journal of Financial Economics, 51(2), 219-244.

Stiglitz, J. E. (1967). A re-examination of the Modigliani-Miller Theorem. Yale University.

Titman, S. \& Wessels, R. (1988). The Determinants of Capital Structure Choice. Journal of Finance, 43(3), 1-21.

Wright, S. H. (2004). Measures of Stock Market Value and Returns for the US Nonfinancial Corporate Sector, 1900-2002. Review of Income and Wealth, 50(4), 561-584.

\section{Appendix 1}

\section{PROJECT: COST OF CAPITAL AND CAPITAL STRUCTURE ANALYSIS}

Choose a firm from the list of firms you are working with in your investment game.

You can find its financial statement information from the website

of "Market Insight": www.mhhe.com/edumarketinsight.

In addition, if you choose to, you can obtain additional information, either from the company itself or from other websites.

For example, use web-links on the course Blackboard site.

Use this information to analyze the cost of capital and capital structure of your firm.

This is a team case.

The report should answer the following questions (a total of 10-15 pages not including tables is recommended):

1. General information (15\%)

background information including the firm's objectives and history (major events, for instance when the firm became public corporation)

current business situation (product line, major competitors and the market situation)

brief description of the firm's organization chart and the top-management team

2. Ownership structure (15\%)

Major shareholders

Information about shares and stock options owned by management

Next questions will be based on the spreadsheet analysis of capital structure using the template that you can get from this file (it's called "Calculations") which currently contain the Oracle example.

This spreadsheet must be printed and presented in total (!) in a readable (reduced) format.

The weight of spreadsheet analysis is $30 \%$

Answer the following Questions:

3. What is the firm's current debt/equity ratio (based on table 3 from "Calculations") ? (10\%)

4. In your opinion, is the firm's debt/equity ratio high or low?

Compare the debt/equity ratio with other firms at the same industry or related industries $(10 \%)$

(use industry report available in edumarketinsight)

5. Is the firm's current debt/equity ratio explained by the firm's financial policy or by the current market conditions? (10\%) 
Look at the firm's debt/equity ratio over the last few years (in book values it can be found, for instance, in edumarketinsight).

6. What is the firm's optimal capital structure according to WACC approach (based on tables 4 and 5 from "Calculations") (10\%)

Provide your recommendations

You should method of trial and error when working on this questions. Change values in yellow columns

7. (bonus question-up to $10 \%$ ) If current debt/equity ratio different from optimal, then what factors, in your opinion, which are not taken into consideration in the Spreadsheet analysis may explain this difference (i.e. which factors may affect the firm's capital structure policy)?

Use information from questions 1 and 2, lecture notes and your imagination

The deadline for submitting the report is $1-30$ p.m., November 22

\section{Appendix 2}

Table 1: Aggregate table for all projects

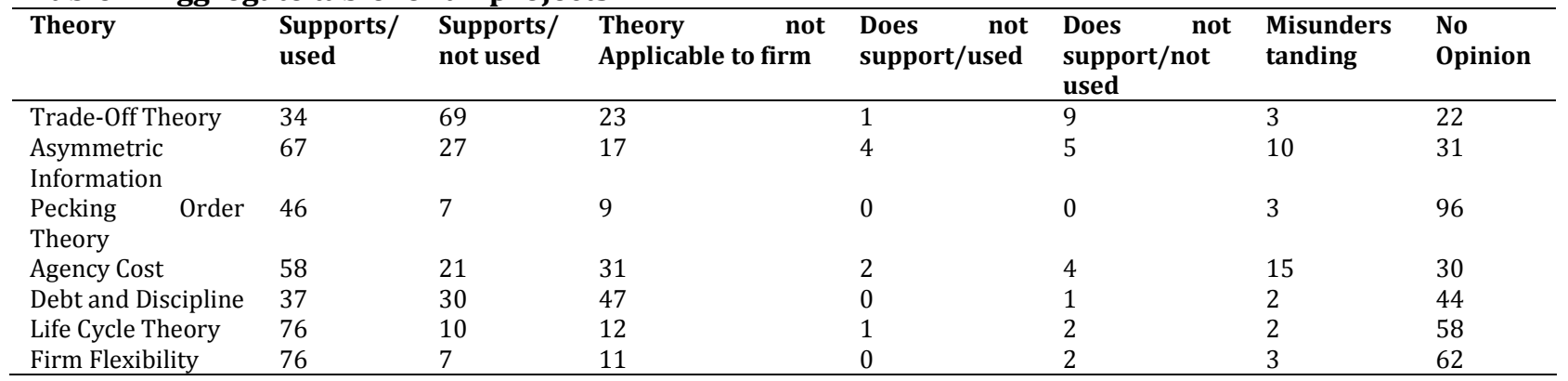

Table 2: Aggregate table for excellent students (Grading from 90 to 100)

\begin{tabular}{|c|c|c|c|c|c|c|c|}
\hline Theory & $\begin{array}{l}\text { Supports/u } \\
\text { sed }\end{array}$ & $\begin{array}{l}\text { Supports/n } \\
\text { ot used }\end{array}$ & $\begin{array}{lr}\text { Theory } & \text { not } \\
\text { Applicable } & \text { to } \\
\text { firm } & \end{array}$ & $\begin{array}{l}\text { Does r not } \\
\text { support/used }\end{array}$ & $\begin{array}{l}\text { Does not } \\
\text { support/not } \\
\text { used }\end{array}$ & $\begin{array}{l}\text { Misunders } \\
\text { tanding }\end{array}$ & $\begin{array}{l}\text { No } \\
\text { Opinion }\end{array}$ \\
\hline Trade-Off Theory & 12 & 11 & 7 & 1 & 0 & 0 & 1 \\
\hline $\begin{array}{l}\text { Asymmetric } \\
\text { Information }\end{array}$ & 11 & 4 & 2 & 0 & 0 & 0 & 15 \\
\hline $\begin{array}{l}\text { Pecking Order } \\
\text { Theory }\end{array}$ & 14 & 4 & 6 & 0 & 0 & 1 & 7 \\
\hline Agency Cost & 15 & 2 & 1 & 0 & 1 & 1 & 12 \\
\hline Debt and Discipline & 9 & 9 & 4 & 0 & 0 & 2 & 8 \\
\hline Life Cycle Theory & 9 & 10 & 5 & 0 & 1 & 0 & 7 \\
\hline Firm Flexibility & 19 & 5 & 1 & 0 & 0 & 0 & 7 \\
\hline
\end{tabular}

Table 3: Aggregate table for students except excellent students

\begin{tabular}{|c|c|c|c|c|c|c|c|c|}
\hline Theory & $\begin{array}{l}\text { Supports } / u \\
\text { sed }\end{array}$ & $\begin{array}{l}\text { Supports } / \mathbf{n} \\
\text { ot used }\end{array}$ & $\begin{array}{l}\text { Theory } \\
\text { Applicable } \\
\text { firm }\end{array}$ & $\begin{array}{r}\text { not } \\
\text { to }\end{array}$ & $\begin{array}{l}\text { Does not } \\
\text { support/used }\end{array}$ & $\begin{array}{l}\text { Does not } \\
\text { support/not } \\
\text { used }\end{array}$ & $\begin{array}{l}\text { Misunders } \\
\text { tanding }\end{array}$ & $\begin{array}{l}\text { No } \\
\text { Opinion }\end{array}$ \\
\hline Trade-Off Theory & 22 & 58 & 16 & & 0 & 9 & 3 & 21 \\
\hline $\begin{array}{l}\text { Pecking Order } \\
\text { Theory }\end{array}$ & 32 & 3 & 3 & & 0 & 0 & 2 & 89 \\
\hline $\begin{array}{l}\text { Debt and } \\
\text { Discipline }\end{array}$ & 28 & 21 & 43 & & 0 & 1 & 0 & 36 \\
\hline Life Cycle Theory & 67 & 7 & 0 & & 1 & 1 & 2 & 51 \\
\hline Firm Flexibility & 57 & 2 & 10 & & 0 & 2 & 3 & 55 \\
\hline
\end{tabular}

